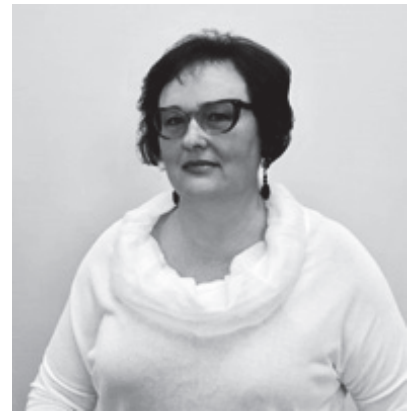

\section{Liolita Bernotienè}

Klaipeda University
Liolita Bernotienè - Klaipèdos universiteto

Humanitarinių ir ugdymo mokslų fakulteto Europos kalbų katedros docentè, daktarè.

Moksliniai interesai: sociolingvistika, diskurso analizè, anglų stilistika, retorika.

Adresas: Klaipèdos universitetas,

Salomėjos Nèries g. 5, Klaipèda, Lietuva.

El.paštas: liolitabernotiene@ku.lt

Liolita Bernotiene: Ph. D., asociate professor at the Department of European Languages, Faculty of Humanities and Educational Sciences, Klaipeda University. Research interests: Sociolinguistics, English Discourse Analysis, English Stylistics, Rhetoric.

Address: Klaipeda University, Salomėjos Nėries str. 5, Klaipèda, Lithuania.

E-mail: liolitabernotiene@ku.lt

\title{
IDIOSYNCRATIC VARIATIONS WITHIN THE METADISCURSIVE MATRIX OF MODERN PUBLIC VERBAL INTERACTION
}

\begin{abstract}
Anotacija
Siekiant išsiskirti iš konvencinio viešųiu kalbų konteksto metadiskursinè matrica pažeidžiama šiais lingvistiniais būdais: 1) neformalusis registras viešojoje erdvejje keičia formalųij; 2) vartojamų laipsniuojamųjų-vertinamųjų būdvardžių gausa pažeidžia objektyvumo ir tikslumo lūkesčius; 3) taikomos pragmatinès-retorinès savivokos strategijos; 4) vulgarizmų ir įžeidžiamų žodžių bei kreipinių gausa; 5) retorinių priemonių įvairovè.

Šių idiosinkretinių variacijų poveikis yra identifikavimosi su klausytoju strategija, nes kalbėtojas pasiekia tokių užsibrèžtu rezultatų, kaip: 1) išsiskirti iš kitų kalbėtojų konteksto dèl kalbos nenuspejjamumo ir autentiškumo; 2) atkreipti dèmesị ị kalbos turinị; 3) iggyti galią, ją išlaikyti bei demonstruoti klausytojams ir taip juos valdyti; 4) sukurti įtampos bei laukimo poveikị; 5) paveikti ir įtikinti klausytojus imtis norimo veiksmo.

PAGRINDINIAI ŽODŽIAI: intertekstualumas, metadiskursinè matrica, emocinè-apeliacinẻ diskurso funkcija, metadiskursiniai lūkesčiai, idiosinkretinès deviacijos.
\end{abstract}

\footnotetext{
Abstract

In order to be distinguished from the conventional verbal interactional context deliberate violations of the metadiscursive matrix are employed:1) the informal register instead of the formal; 2) gradable adjectives and superlatives violate the expectation of objectivity and accuracy; 3) the self-conscious pragmatic-rhetoric strategies; 4) ample use of vulgarisms and offensive addresses; 5) a diversity of rhetoric means.
} 
These idiosyncratic variations function as the strategy of identification with the audience, and the effects achieved are as follows: 1) gaining attention; 2) distinguishing oneself from the context of similar speakers; 3) gaining and demonstrating power; 4) suspense; 5) convincing and persuasion for taking action.

KEY WORDS: intertextuality, metadiscursive matrix, emotive-appellative discourse function, violation of metadiscursive expectation, idiosyncratic deviations.

doi:http://dx.doi.org/10.15181/rh.v22i0.1626

All types of discourse are based on intertextuality: in particular social situations the process of communication is enabled only because both speakers and listeners are sharing specific or typical linguistic matrix of expression under particular social circumstances, i.e. "the participants share procedural knowledge about systems of pragmatic principles and social practices, above all those of verbal interaction" (Fetzer 2013, 6). So successful communication is realized in case when listeners recognize the metalanguage or intertextual patterns of communication "based on their memories of things they have said, heard, seen, or written before" (Johnstone 2008, 3). It means that discourse can be realized in a diversity of social (formal and informal) levels and in each case it is intelligible according to a particular paradigm of linguistic matrix.

According to Barbara Johnstone (2008, 139), intertextuality is a term that defines an experience with prior discourse which is one of the resources the listeners are making use of while interpreting the text, i.e. prior discourse and its categories are evoked and created as we interact on the basis of previously created expectations about how to interpret utterances. It may imply that while communicating we select formulas as "repeatable wholes and we re-use them as text-building strategies while building new meanings" (Ibid, 139). Consequently, all types of communication are based on syntagmatic and paradigmatic intertextuality. This factenables each text or utterance to be imparted and understood due to particular conventional, socially contextualized metadiscursive linguistic cues shared between the speaker and the listener. For instance, David Zarefsky considers that a public speech is a composite result of communication between the speaker and the target audience based on mutual comprehension of the rhetoric situation where one of the strategies of the speaker is to identify with the audiences, (cf.: Zarefsky 2011, 54). The linguist means that it is namely the listeners who subconsciously allow to 
create the rhetoric situation, and this fact makes the speaker select which ideas have to be emphasized and, at the same time, which ways and modes are to be implemented in order to best realize the purposes of the speech (cf.: Zarefsky 2011, 42).

The term metadiscursive includes the aspects of texts that affect the relations of authors (speakers) to readers (listeners), in order to mark the direction and purpose of a text and announce the intentions of the author; in other words, metadiscursive linguistic matrix serves to reveal author's awareness of the reader (listener) and the need for responsive approach, empathy, and compliance to the anticipation on the part of the listener which, ultimately, results in interaction. In this respect, the term may include the categories of both: register (tone, a set of appropriate vocabulary and grammar for a particular social situation), and style (typical choices for an individual). So, traditionally, communication is successfully realized when listeners recognize the systems of metadiscursive linguistic principles which match adequately with the social practices.

Traditionally, language is expected to be specified according to the speaker's social and personal identity in the society, for instance, President of a country, as opposed to an ordinary technical or manual worker in the job market, would be expected to employ diverse linguistic systems, no matter that they are all holders of one and the same English language. Moreover, we are all used to the idea, that language may actually be a means of characterizing a person's identity who, as a representative of a specific class or profession, possesses identifiable linguistic matrix for specific social positions and occasions. In this context, normally, the listeners know instinctively what to expect onbehalf of the government official or, on the other hand, on behalf of the manual worker, prisoner, or a student, etc. and to accept him/her as an appropriate representative of his/her social status not only in the behavioral patterns but also in the linguistic verbal interaction.

However, in modern public verbal interaction, be it in social networks, mass media, or Twitter, etc., a tendency of violation of the listener's (reader's) expectation concerning the established both syntagmatic and paradigmatic metadiscursive matrix is ever more conspicuous.

The object of the research is the analysis of the deliberately confused linguistic matrix of social identities in public verbal interaction which 
demonstrates evident linguistic deviations from the expected metadiscursive matrix with the purpose of satisfying the intended emotional-appellative discourse functions.

However, the motivation of the analysis is comprised by the fact, that listeners' expectations most frequently in modern verbal interaction (both written and oral)are violated by the deviations from the established norms mainly because of the appellative-emotional discourse functions that are intentionally and deliberately imposed on verbal interaction by the speakers. The result is the effaced boundaries between what is expected and what is actually realized. The stylistic effect of such idiosyncratic deviations which violate the expected metadiscursive matrixis that the attention is attracted by being distinguished from the social context of expectation.

Stylistics, in general, supports the idea that what achieves the stylistic value and effect is usually asubjectively imposed deviation from the standard patterns and structures. According to Paul Chilton and Christina Schäfner $(2002,18)$, "discourse first refers to the phenomenon of contextualized real-time utterances, as contrasted to sentences which are considered to be decontextualized syntactic constructs" (as taken from the grammar book). So, it is namely what can be called idiosyncratic variation (or deviation from the established matrix in a particular social situation) that is deliberately employed in building public relations the main goal of which is to manage the dissemination of desired information between an individual (or an organization) and the public in the most unexpected and unpredictable way with the intended outcome.

The purpose of the present article is to identify the linguistic deviations which violate the expectation of the conventionalized linguistic matrix of communication in public verbal interaction.

The tasks are as follows:

- To define the patterns of expected matrix;

- To analyze the violations of linguistic matrix;

- To compare the linguistic idiosyncratic deviations with the standard environment;

- To establish the stylistic effects and the results achieved;

- To identify the structures of power that build up the appellative discourse function. 
Methods applied for the research are:

- Analytical - to analyze the lexical and syntactic structures of the deviations;

- Descriptive - to identify the new contextual environments of the linguistic structures;

- Comparative - to make comparisons with the matrix of intertextuality.

The mechanism of verbal interaction

Traditional attitude towards building a conversation is based on conscious or most frequently subconscious repetition: if we are not repeating exactly the same words in the same recurrent situations, at least speakers are repeating syntactic structures, rhetoric patterns, structural text-building forms, plots, etc., moreover we are repeating not only others but even ourselves. On the other hand, native and foreign language acquisition and usage also relies on repetition. On the basis of abundant amounts of texts language corpus linguists have already compiled more or less defined register categories of appropriate linguistic matrix (form or mold) in definite recurrent social language usage situations, cf.: (Ferguson 1994, 20) “A communication situation that occurs regularly in a society(in terms of participants, setting, communicative functions, and so forth) will tend over time to develop identifying markers of language structure and language use, different from the language of other communication situations". It means that language users acquire not only isolated words and morphological and syntactic structures but while using language for definite reallife situations they also acquire a knowledge of the appropriate environmental context of application and functioning of the register of particular vocabulary and structures. It is namely the latter feature that allows for the speakers and listeners to orient themselves throughout the conversational map which, ultimately, guides them towards the intended pragmatic purposes. The knowledge of the linguistic metadiscursive matrix builds up intertextuality expectation, in other words: "conventionalized verbal form associated with the conventionalized purpose or occasion"i.e." knowing the ways of interacting and general strategies of interpretation that are characteristic of a situation" (Johnstone 2008, 156), which, when satisfied, 
comprises intelligibility and understanding between the participants of verbal interaction.

However, the process described would result in a mechanical computer language which, naturally, people do not actually speak. No matter what restrictions intertextuality expectations might impart, in real-time communication there can be neither exactly identical recurrent situations, nor identical speakers. Each individual speaker distinguishes one's identity not only concerning phonological and lexical levels but also structural-grammatical ones. At this juncture, the term style should be mentioned, which emphasizes each speaker's individuality by authentic linguistic choices: the more deviant and unexpected those choices are, the more idiosyncratic the individuality is revealed. In fact, freedom with language competencies that an individual can afford to allow oneself, in other words, idiosyncratic variations frequently surpassing the established metadiscursive matrix of a particular register, can be referred to as idiolect. As PaulCobley (2001, 126) puts it idiolect "is a personal variety of speech" used in oral communication which can't be in any way "identical with the system used by any other person" (Bennett 1998, 4).

Idiolect is to be tightly related with the individual identity of a single person, no matter what social walks he/she may seek to represent or identify with. It is to be related with the self-consciously expressive, emotional and appellative discourse functions the speech intends to satisfy and perform. Thus, it implies that each public speaker seeks to stand out as a unique distinguished personality to be memorized, due to the fact that "the interpersonal difference does exist" (Rajimwale 2006, 108) in the way people organize their discourse and affect the audience for achieving the intended pragmatic results.

Most frequently language is employed as a tool in order to do multiple things, such as to perform political and ideological manipulations and gain power.

\section{Idiosyncratic linguistic deviations}

However, on the other hand, language serves a lot of functions. According to James Paul Gee $(1999,2)$, "language not only allows us to do various things but also allows us to be things by acquiring socially sig- 
nificant roles". David Crystal $(2008,148)$ defines the term discourse as "a behavioral unit which has a pre-theoretical status in linguistics: it is a set of utterances which constitute any recognizable speech event, e.g. as a conversation, a joke, a sermon, speech or interview". Chilton and Schäffner $(2002,18)$ emphasize among other features that "discourse refers to a stretch of real-time utterances, for instance: speech at a party, political rally, a sequence of speeches, such as parliamentary debate or a single language event; subsequently, discourse is referred to as " the totality of utterances in a society viewed as an autonomous evolving entity in relation to which individuals have partial self-determination, as particular sets of utterances and practices are inseparable part from the concept of power". On the other hand, David Howarth $(2000,1)$ considers that "discourse constitutes the socialand political world and its analysis should expand to many branches of the human social science".

Mikhail Bakhtin, 1986, and Julia Kristeva, 1986, introduce the term "appropriation" which may be explicated as being "self-consciously strategic" (Johnstone 2008, 139-140), in other words, speakers guided by pragmatic purposes of their speechre-use or borrow ways of successful talking making them their own self-expression discourse strategies. However, recent public verbal interaction demonstrates that speakers more freely employ specific idiolect as if deliberately seeking to shock and impress the audience. In modern verbal interaction violation of metadiscursive expectation can function as powerfully effective mechanism in seeking, first of all, to be distinguished from the crowd of rivals, heard, and remembered, which, ultimately, attracts and convinces the audience to take desired measures and steps. The deviations from the accepted norms refer not only to the syntagmatic (horizontal) intertextuality, meaning: words, phrases, expressions, plots in their adequate contexts but also to the paradigmatic (vertical) - the principles on which texts are built on previous texts of the same category (cf.: Johnstone 2008, 139).

The discourse which is completely unlike anything previously acknowledged would either be completely misunderstood, or, on the other hand, would stand out from a number of texts that are based on conventional linguistic matrix. According to David Crystal, for instance, to put a question to a politician practically means "a linguistic game par excellence, i.e. it provides a chance to do several things - to focus public attention on 
an issue, express identity with a party political line, or cause trouble for the other side. It is also a chance to get noticed, settle old scores or repay a constituency debt" $(2003,379)$.

What are these linguistic factors that enable speakers to create their own authentic way of speaking, and what are these idiosyncratic linguistic variations that perform the emotional-appellative discourse function in the text which so powerfully affects the modern audiences? In other words, what deviations from the expected linguistic matrix of the listener assist the speaker in achieving his/her communication goals?

1. Firstly, it is the register factor: which is to be understood as a set of specific markers of language structure and language use in particular social situation. In public verbal interaction speakers deliberately insert colloquial informal vocabulary or language structures in the communicative slots that seemingly require the formal or more official register. President Donald Trump's public speeches and social network pages abound in colloquial register phraseology and structures, and it is mostly one of the reasons why he is quoted to such a high degree all over the world. The phrases that evidently violate the metadiscursive matrix have already stuck in the memory of the whole world because of the discrepancy between what is expected and what is produced under particular circumstances. The result is achieved by the power of shock and unexpectedness. Just a few examples may be provided here as well:

"I always say, Trojan horse. Watch what's going to happen, folks. It is not going to be pretty." http://www.fox25boston.com/news/trending -now// full- transcript-heres-what-donald -trump-said-about-lies-immigrationpolicy/434596691

"You know, it really doesn't matter what the media write as long as you've got a young, and beautiful, piece of ass".http://www.marieclair.co.uk./entertainment/people/donald-trump-qouts-57213

"How low has President Obama gone to tap my phones during the very sacred election process. Bad (or sick) guy!" http://twitter.com/realDonaldTrump

On the other hand, President's reaction towards the death of former Cuban President Fidel Castro while Cuban exiles in the USA were cheering in the streets of little Havana in Miami was just an exclamation mark as he simply tweeted: 
"Fidel Castro is dead!" Fidel Castro Dies. (2016, November 26) Transcript. CNNNEWSROOM.CNN. Retrieved from http://transcripts.com./ TRNSCRIPTS/1611/26/cnr.02.html

As it was demonstrated above, President Donald Trump employs widely acknowledged dead metaphors (like Trojan horse), at the same time he makes allusions to historical facts known to every person in the world, and what seems most shocking, he ironizes such a tragic and dramatic event, like President Abraham Lincoln's assassination in Hamilton Theatre by trolling Hillary Clinton and her team SJW (social justice warriors) who demand their "safe spaces" by saying that "the theatre should be a safe place". One of the commentators replies: I think, the history says the theatre is one of the least safe places for Presidents. H3h3Productions. (2016). Why is Donald Trump so TRIGGERED? [VoD]. Retrieved from http:// www.youtube.com.wtch??v-=ctmZGSyMFy4

As it often happens on the internet, the comment is witty and relies on some kind of prior knowledge of a particular context. In this case the context is historic, relating to President Lincoln being shot in the theatre. Here Donald Trump demonstrates his attitude in a shallow manner towards the role of social organizations which complicate his election campaign by those who support and defend various vulnerable social groups like feminists, LGBT, vegans, black lives matter, etc.

The intended audience is not identified - it may be everyone and no one at the same time, as it is always in social media. If the thought is witty, interesting, or even insulting, it usually gathers attention from others. Language is simple, informal, derogatory, riddled with grammatical mistakes and jargons, like trolling, sjw, cuz, etc.

On the other hand, vulgarisms and offensive words are not at all accidental, on the contrary, they are part of a well-thought self-conscious discourse strategy: those who feel insulted will forget neither the words, nor the offender. They will talk about it and contemplate over the insults, like: "You are uneducated people but I like you because you will vote for me." And they voted, because of the strategies employed. There is nothing worse than not being spoken about, no matter well or badly.

For comparison, Steve Jobs in his speech "Stay Hungry, Stay Foolish" given to the graduates of Stanford University on June 12, 2005 (link to the full text of the speech: http://news.stanford.edu/news/2005/june15/ 
jobs-o61505.htm), also practices colloquial approach towards his audience as if trying to identify himself with the students. He starts with strong beginning by paying compliments to the audience: "I am honored to be with you today at the presentation of diplomas of one of the best universities in the world" Further, he demonstrates some degree of humility, admitting that he himself had not finished college. Just with a few sentences he creates a positive attitude of the audience towards himself and thus increases the susceptibility of his speech by presenting it in colloquial tones rather than official. For instance, he uses first names for introducing famous personalities as they are his friends: "Wozniak and I started Apple".

2. Secondly, very frequently colloquialisms verge on the brink of being vulgar and offensive, cf. second example and some others:

“....in some cases they are murderers, drug lords, drug problems.” https://www. nytimes.com/2016/10/10/us/politics/transcript-second debate.html? $\mathrm{r}=0$

"...I will knock the hell out of ISIS" http://nytimes.com/2016/10/10/ us/politics/transcript-second-debate.html? $\mathrm{r}==0$

"by God's will we will slaughter you pigs, I swear, we will..." http://twitter. com/realdonaldtrump

"She is a dog who wrongly comments on me." http://www. Independent. co.uk./news/world/americans/us-elections/Donald-trump-sexist-quotscomments-tweets7353006.html

"Such a nasty woman." (about Hillary Clinton). http:// www.politico.com/story/2016/10/full-transcript-third-2016-presidential-debate-230063

3. Thirdly, ample usage of gradable adjectives, such as: stupid, horrible, arrogant, great, etc., instead of the expected objective non-gradable where necessary. The gradable adjectives most frequently are employed in their superlative forms, which also serves for creating the subjectively-evaluative character of the message and violate the expectation of the principle of objectivity and accuracy, like in the following examples:

"I' $m$ the most successful person ever to run for the presidency." https:// www.bloomberg.com/politics/articles/2015-06-01

"I will be the greatest jobs producer that God ever created." https://www. nytimes.com/2017/01/11/us/politics/trump-press-conference-transcript.html 
"... a total and complete shutdown of Muslims entering the United States...." https://www/politico.com./story/2016/08/donald-trump-terrorismspeech-227055

“...we have the greatest people on Earth in our military...." https://www. nytimes.com/2016/11/10/us/politics/trump-speech-transcript.html

"I have tremendous respect for women and the many roles they serve that are vital to the fabric of our society and our economy". https://twiter.com/ realdonaldtrump

"We will make America great again."

"America will no longer settle for anything less than the best."

"We expect to have great, great relationships."

http://www.americanrhetoric.com/speeches/donaldtrumpPresidentelectvictoryspeech.htm

The use of superlative degree adjectives and strong phrases of abundant intensifiers that support the impact on audiences create the effect of power and dominating. Moreover, those adjectives express maximum quality of the feature, as President deliberately employs excessive exaggerations of either positive or negative connotations. So it is always either extraordinarily black or white - there is nothing in between. The sharply contrasting antonyms strike the listeners by the straightforwardness and leave no space for another treatment of reality by creating an idea of confidence credits given to the speaker. It is namely the mechanism of gaining power by imposing an illusion of being irreplaceable, being the only one, and at the same time being the guarantee of the desired situation to come for the whole country and each personally.

4. Fourthly, the self-conscious pragmatic-rhetoric strategies include the first person pronoun, both singular and plural, which is amply demonstrated in the above examples, and also in Steve Jobs' speech:

"If I had never dropped out, I would have never dropped in"; or:

"My mother had never graduated from college and $\boldsymbol{m y}$ father had never graduated from school".

"And whenever the answer has been "No" for too many days in a row, I know I need to change something."

Personal pronoun in public verbal interaction allows to efface the distance between the participants of communication, helps as if to assume personal responsibility and remove it from the listeners' shoulders, which 
they are most willingly to admit. This simple linguistic trick plays its adequate role in making audiences to be persuaded.

5. Ample use of rhetoric means, especially repetition.

"We will double our growth and have the strongest economy anywhere in the world. At the same time, we will get along with other nations willing to get along with us. We will be. We'll have great relationships..."

"No dream is too big; no challenge is too great; nothing we want for our future is beyond our reach. America will no longer settle for anything less than the best."

http://www.americanrhetoric.com/speeches/donaldtrumpPresidentelectvictoryspeech.htm

Repetition can involve not only the same repeated successive words, phrases but also structures. That is why repetition can acquire a diversity of forms, such as: alliteration, parallelism, chiasmus, antithesis, anadiplosis. While President of the USA repeats the same sentence structure (syntactic parallelism), Steve Jobs practices numerous forms of repetition:

"The only way to be truly satisfied is to do what you believe is great work. And the only way to do great work is to love what you do." (Anadiplosis);

"You cannot connect the dots looking forward; you can only connect them looking back." (Antithesis);

"Do not waste time on the life of someone else. Do not be trapped by dogma. Which is living with the thoughts of other people. Do not let the noise of others' opinions to destroy your own inner voice." (Anaphora).

6 . However, the excessiveness of lexical and rhetoric means is contrasted with the simplicity of the syntactic structure where the simple threemember sentence pattern is prevailing, as it is best memorable, easy to follow and catch, and does not encumber the audience with ambiguities. Future simple tense frequently employed by Donald Trump delineates the perspective.

Conclusions

1. Violation of metadiscursive expectation is deliberate, and by no means accidental, as it is a self-conscious discourse strategy which is employed when speakers seek togain attention, be distinguished from a broader background of rivals and assists in achieving dominance and power. 
2. Linguistic deviation patterns violate the matrix of expected register by setting it apart from the social situation, and the informal register is inserted in the official communicative slots.

3. Idiosyncratic deviations perform the emotional-appellative discourse function.

4. Other linguistic means, such as: gradable adjectives, superlative degree, first person pronoun, vulgarisms and offense words and address, and repetition combined with the simplicity of syntactic structure buildup the self-conscious pragmatic-rhetoric strategy of the discourse.

\section{References}

Bennett 1998 - P. Bennett. Comparative Semiotic Linguistics. A Manual. USA.

Chilton \& Schäffner 2002 - P. Chilton \& C. Schäffner. Politics as Text and Talk: Analytic Approaches to Political Discourse. The Netherlands: John Benjamin's Publishing House.

Cobley 2001 - P. Cobley. The Routledge Companion to Semiotics and Linguistics. Routledge.

Crystal 2003 - D. Crystal. Cambridge Encyclopedia of the English Language. Cambridge: Cambridge University Press.

Crystal 2008 - D. Crystal. A Dictionary of Linguistics and Phonetics. Sixth ed. Cambridge: Cambridge University Press.

Deckert \& Vickers 2011 - K. S. Deckert \& C. H. Vickers. An Introduction to Sociolinguistics. London: Bloombury, UK.

Ferguson 1994 - C. Ferguson. Dialect, register, and genre: Working assumptions about conventionalization. In: D. Biber \& E. Finegan (eds.), Sociolinguistic Perspectives on Register. New York: Oxford University Press, 15-30.

Fetzer 2013 - A. Fetzer. The Pragmatics of Political Discourse. The Netherlands: John Benjamin's Publishing House.

Gee 1999 - J. P. Gee. An Introduction to Discourse Analysis: Theory and Method. Fourth Ed. Routledge.

Howarth 2000 - D. Howarth. Discourse. Open University Press.

Jonstone 2008 - B. Jonstone. Discourse Analysis. Second ed. Blackwell Publishing House. Rajimwale 2006 - S. Rajimwale. Handbook of Linguistic Terms. SARUP \& SONS.

Zarefsky 2011 - D. Zarefsky. Oratorystès menas. Vilnius. Alma littera. 


\section{Liolita Bernotienè}

\section{IDIOSINKRETINESS VIEŠOJO ŽODINIO BENDRAVIMO METADISKURSINES MATRICOS VARIACIJOS}

Santrauka

Diskursas realizuojamas įvairiuose socialiniuose lygmenyse, tiek formaliuose, tiek ir neformaliuose. Kiekvienu viešosios kalbos atveju žodinė interakcija įmanoma tik tada, kai klausytojo lūkesčius atitinka tam tikra konvenciškai nusistovejjusi lingvistinès matricos paradigma, kurią vartoja kalbètojas tam tikroje socialinejje situacijoje. Tačiau klausytojas išgirsta ir atpažįsta tą lingvistinį kodą, kurio tikisi apibrèžtu laiku ir konkrečioje vietoje bei konkrečia proga. Ši bendravimo mechanizmą daugelis lingvistų vadina intertekstualumu, kuris laikomas matrica, pagal kurią vartojame ir atpažistame tam tikras lingvistines kategorijas tam tikrose socialinėse situacijose. Kalbėtojai remdamiesi savo ilgalaike kalbine patirtimi susikuria lūkestị, kurị realizavus įvyksta visavertis bendravimas.

Terminas metadiskursinè matrica reiškia kalbančiojo autoriaus dẻmesị klausytojo lingvistiniams lūkesčiams, kuriais vadovaujamasi viešojoje kalboje. Tradiciškai žodinis bendravimas viešojoje erdveje yra sẻkmingas tada, kai kalbètojas gerbia klausytoją ir atsakingai reaguoja ị jo lūkesčius atitinkamai formuluodamas savo kalbą.

Dažniausiai kalbos metadiskursiniai lūkesčiai formuojasi socialiniu pagrindu, pavyzdžiui, tikimasi, kad šalies ar verslo įmonès prezidentas, priešingai nei įmonės darbininkas, tam tikros retorinès situacijos atveju viešojoje kalboje rinksis lingvistines struktūras, labiau atitinkančias oficialųji registrą, nors jie visi kalba ta pačia anglu kalba. Juolab kad kalbos raiškos priemonių pasirinkimas gali tapti asmenį identifikuojančia charakteristika pagal socialinius profesijos, amžiaus, padèties visuomenėje ir kitus požymius.

Tačiau šiuolaikiniame viešajame žodiniame diskurse, socialiniuose tinkluose bei masinèse informacijos priemonèse pastebima klausytojo (skaitytojo) intertekstualiųių lingvistinių lūkesčių pažeidimų bei nukrypimų nuo registro konvencinių modelių. Tačiau šie deviaciniai kalbos modeliai 
tampa apeliacine diskurso strategija, siekiant išskirtinumo ir kalbos efektyvumo.

Analizės tikslas yra nustatyti lingvistines deviacijas, kurios pažeidžia viešojo žodinio bendravimo socialinę konvencinę metadiskursinę matricą.

Analizė parodè, kad siekdamas išsiskirti iš konvencinio verbalinio bendravimo konteksto, atitinkančio socialinius lūkesčius, kalbėtojas tikslingai pažeidžia metadiskursinius klausytojo lūkesčius šiais lingvistiniais būdais: 1) neformalusis registras įterpiamas į tas komunikacines socialines situacijas, kurios tradiciškai reikalauja formaliojo registro; 2) vartojamų laipsniuojamųjų-vertinamųjų būdvardžių gausa, ypač jų aukščiausiasis laipsnis, pažeidžia objektyvumo ir tikslumo lūkesčius viešajame diskurse; 3) taikomos tokios pragmatinès-retorinès savivokos strategijos, kaip pirmojo asmens vienaskaitos ir daugiskaitos įvardis; 4) vulgarizmų ir įžeidžiamų žodžių bei kreipinių gausa; 5) retorinių priemonių ịvairovè, ypač dažnos pakartojimo formos.

Tačiau leksinių ir retoriniu strategijų perteklius kontrastuoja su sintaksinès sakinio struktūros paprastumu: vyrauja paprastojo sakinio trinarè struktūra kartu su veiksmažodžio paprastosiomis esamojo, būtojo ir ypač būsimojo laiko formomis.

Šiu idiosinkretinių variacijų poveikis klausytojui yra tikslingai suprojektuotas ir veikia kaip viešosios kalbos apeliacinè strategija. Kalbėtojas pasiekia užsibrèžtų rezultatų: 1) išsiskirti iš kitų kalbètoju konteksto dèl kalbos nenuspejjamumo ir autentiškumo; 2) atkreipti dèmesị i kalbos turinį; 3) iggyti galią, ją išlaikyti bei demonstruoti klausytojams ir taip juos valdyti; 4) sukurti įtampos bei laukimo poveikį; 5) paveikti ir ịtikinti klausytojus imtis norimo veiksmo.

Tyrimui naudota medžiaga - viešųų JAV prezidento Donaldo Trumpo ir APPLE prezidento Steve Jobso kalbų pavyzdžiai. 